\title{
Hierarchies. Lotta Support, Little Science? \\ Scientists and Secretaries in the Max Planck Society
}

\author{
Birgit Kolboske \\ Max Planck Institute for the History of Science
}

\begin{abstract}
Contrary to common belief, organizational structure is never gender neutral; it is just that since "men in organizations take their behavior and perspectives to represent the human, organizational structures and processes are theorized as gender neutral." (Joan Acker 1990). The Max Planck Society is a gendered organization whose employment structure in the twentieth century featured a clear gender segregation. The following highlights two areas of a research project on the history of women and gender equality in the Max Planck Society-the one where only very few women were admitted: science; and the one where most of them worked most of the time: the office.
\end{abstract}

\section{MORE SUPPORTERS THAN SCIENTISTS}

"Gender is a cultural framework that defines masculinity and femininity as different and unequal." 1

Contrary to common belief, organizational structure is never gender neutral; it is just that since "men in organizations take their behavior and perspectives to represent the human, organizational structures and processes are theorized as gender neutral." 2 The Max Planck Society, "Germany's most successful research organization, “3 is of course a gendered organization. Also it is a very hierarchical one. In keeping with this, its employment structure maintained at least for the first fifty years a clear gender segregation, with men doing research and women supporting them, most of them as secretaries.

1 Abbate, 2017, p. 3.

2 Acker, 1990, p. 142.

3 https://www.mpg.de/short-portrait (15.02.2020). 
According to the first Facts \& Figures (Zablenspiegel) published by the Max Planck Society in 1974, there were a total of 6,954 staff members, of which 2,837 ( $=43$ per cent) were female and 3,757 ( $=57$ per cent) were male. ${ }^{4}$ Figure 1 shows a table breaking down personnel into scientific members, scientific staff, technical staff, administrative staff, other services, skilled workers, non-skilled workers and cleaners, according to gender. Not surprisingly, the majority of female employees figured among the administrative staff and cleaners while being conspicuously absent from the scientific staff, not to mention Members.

Almost twenty years later, Sonja Munz proved in her empirical investigation on the occupational situation of men and women in the Max Planck Society that still not much had changed in this respect. In 1991, women were still predominantly hired as executive and departmental secretaries, as secretaries and typewriters; whereas men were hired in significantly higher numbers as project staff, for IT, general and technical services. $^{5}$

When the gender makeup of a profession flips, when it feminizes as it has happened in case of the secretary, people often assume that the work became simpler. (Unlike when a field becomes masculinized, and the assumption reverses: that the work became more difficult or complex. $)^{6}$ Since the late nineteenth century secretarial work has been viewed as women's work: (type-)machinery and automation lead to its feminization - and subsequent loss of prestige. Technological and digital revolution did not change this, though it changed the perception of computer operation and programming, which in the 1940s, 1950s was also regarded as women's work but acquired a distinctly masculine image with the gain of prominence and influence. ${ }^{7}$

The following is a tour d' horizon across a research project on the history of women and gender equality in the Max Planck Society, highlighting two areas: the one, where only very few women were admitted-science; and the other, where most of them worked most of the time- the office.

4 Max-Planck-Gesellschaft, Zahlenspiegel der Max-Planck-Gesellschaft 1974, 1974, 2. This still corresponds to the actual ratio, which was 44.4 per cent female employees as of December 31, 2018. https://www.mpg.de/facts-and-figures (8.2.2020).

5 Munz, 1993, p. 116.

6 Hicks, 2017, pos.195.

7 Hicks, 2017, pos. 190. 
Figure 1: Max Planck Society staff according to work area and gender ${ }^{8}$

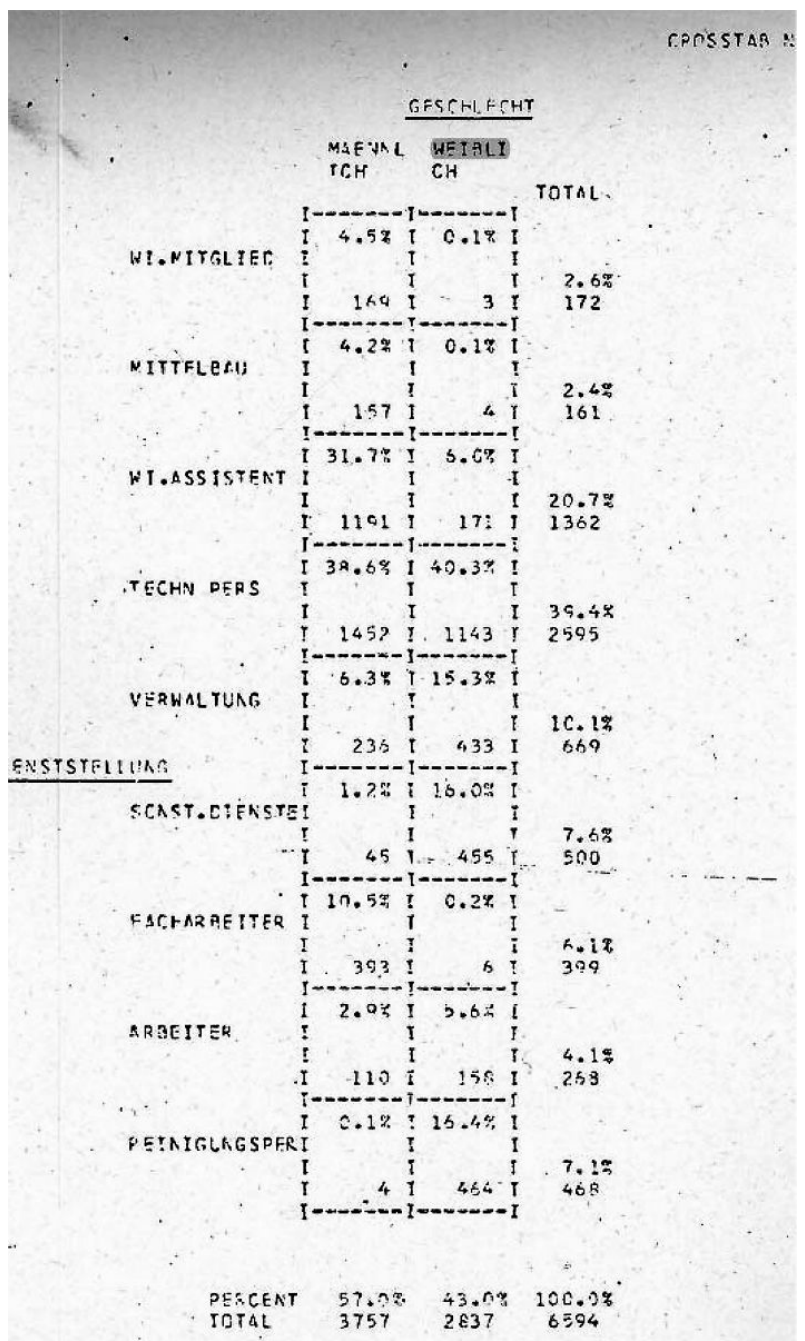

8 Max-Planck-Gesellschaft, Zablenspiegel 1974, p. 15. 


\section{SCIENTISTS}

\section{LOST OPPORTUNITIES}

Germany has a rich, albeit authoritarian, science tradition and its research system is strongly marked by hierarchies and relationships of dependency. ${ }^{9}$ The Max Planck Society is both benchmark and testament to this. Looking at the ruptures and inconsistencies that marked the post-war careers of women in the Max Planck Society, it can clearly be seen that careers for female scientists may have been easier to achieve in its predecessor organization, the Kaiser Wilhelm Society (1911-1948). ${ }^{10}$

When the Max Planck Society was founded in Göttingen in 1948, three of the former 13 female department heads of the Kaiser Wilhelm Society remained in Berlin-plant geneticist Elisabeth Schiemann (1881-1972), physician and cytologist Else Knake (1901-1973), and chemist Luise Holzapfel (1900-1963). In 1946, both Knake and Schiemann were appointed as professors at the newly opened Berlin University. This had to do with the denazification policy of the Allies. Unlike many of their colleagues, neither Schiemann nor Knake had been incriminated in the Nazi regime. ${ }^{11}$ In August 1946, Knake was the first woman ever to be appointed provisional dean of the Medical Faculty, from October 1946 she acted as deputy dean. ${ }^{12}$ Yet, in the same year, Schiemann laconically commented in a letter to her friend Lise Meitner (1878-1968): "Obviously chairs are still not considered for women. "13 Within the newly founded Max Planck Society their careers stagnated or were even cut short compared to those of their male colleagues, who, despite party membership, could continue their careers without any hiccups, as was the case for Wilhelm Rudorf. ${ }^{14} \mathrm{~A}$ fact that seemed "unconceivable" to Schiemann, as she told President Otto Hahn in

9 See e.g. Friederici, 2019, p. 124.

10 The most comprehensive study so far has been provided by Vogt, 2007.

11 On 16 December 2014, Yad Vashem honoured Elisabeth Schiemann as a "Righteous among the Nations." https://righteous.yadvashem.org.

12 Kubicki/Lönnendonker (eds.), 2002.

13 "Ordinariate kommen wohl auch weiterhin für Frauen nicht in Betracht." Sche$i c h, 2002$, 278. For more on the friendship between Schiemann and Meitner, see: Scheich, 1997, pp. 153-157.

14 Rudorf was a member of the NSDAP and Supporting Member of the SS notwithstanding he was in 1946 entnazifiziert, cf. Heim, 2002; Hachtmann, 2007, p. 1114. 
a letter. ${ }^{15}$ Not only did the post-war careers of their male colleagues run smoothly; they once again held positions that allowed them to impede the professional development of female scientists, despite the scientific reputation and political standing of these women.

Thus, Rudorf ${ }^{16}$ and Stubbe ${ }^{17}$ were able to thwart Schiemann's attempts to establish a Max Planck Institute for Crop Research-especially one directed by her. But at least Schiemann became a Scientific Member of the Max Planck Society in 1953. The same year that Else Knake was finally appointed Head of the Department for Tissue Engineering at the Max Planck Institute for Comparative Hereditary Biology and Pathology run by Hans Nachtsheim. Yet, in the following years, any attempt in the Biology \& Medicine Section (BMS) to appoint her a Scientific Member failed mainly due to Nachtsheim's veto, as can be concluded from the records. ${ }^{18}$

That is, the opportunity for a badly needed paradigm shift was missed in the Max Planck Society. This opportunity had probably been already

15 "Unbegreiflich“, Schiemann to Hahn, 22. 8.1946, AMPG, III. Abt., Rep. 14A, Nr. 2750, BI. 5R.

16 Rudorf to Rajewksy, Vorsitzender der BMS des WR der MPG zur Förderung der Wissenschaften, 27 April 1953, III. Abt., Rep. 14A, Nr. 2750, Bl. 463-464; Rudorf to Telschow, 30 April 1953, III. Abt., Rep. 14A, Nr. 2750, Bl. 465; Rudorf to Geheimrat Dr. Kissler, Vorsitzender des Vorstandes der Landwirtschaftichen Rentenbank, 5 May 1953, III. Abt., Rep. 14A, Nr. 2750, Bl. 461. Georg Melchers to Hans Kuckuck, 9 September 1953, AMPG, III. Abt., Rep.75, Korrespondenz, Bd. 6.

17 Forstmann in a letter to Benecke, 9 March 1953, III. Abt., Rep. 14A, Nr. 2750, Bl. 517-518, in which Walter Forstmann informed Otto Benecke about Stubbes negative stance on "Verschmelzung seines [Stubbes] künftigen Instituts mit dem vom Kuckuck-Schiemann".

18 Regarding the efforts to appoint Knake as a Scientific Member, see e.g. the memo made by Otto Benecke from 13 July 1954, in which he notes: "Herr Professor Rajewsky hat Herrn Professor Nachtsheim mitgeteilt, dass er sich für die Ernennung von Frau Knake zum Wissenschaftlichen Mitglied aussprechen würde; und hat um Herrn Nachtsheims Hilfe gebeten." AMPG, II. Abt. Rep. 1A, Wissenschaftlicher Rat 9_m2_13_06_1955. — On Knake's continued exclusion see e.g. Auszugsweise Abschrift aus Aktenvermerk über Besprechung in der Verwaltungsstelle Berlin am 23.4. 1955, "Zur Frage der Ernennung von Frau Prof. Knake zum Wissenschaftlichen Mitglied des Max-Planck-Instituts für vergleichende Erbbiologie und Erbpathologie“, AMPG, II. Abt., Rep. 1A, Wissenschaftlicher Rat 9_m2_13_06_1955-7; the letter from Otto Benecke to Nachtsheim from 18 June 1956, AMPG, II. Abt., Rep. 1A, Wissenschaftlicher Rat 10_m2_11_06_1956; or the letter from Generalsekretär Hans Ballreich an den Vorsitzenden der BMS, Hans Bauer vom 15 January 1962, AMPG II. Abt., Rep. 1A, Wissenschaftlicher Rat 16_m2_22_05_1962. 
lost, when, in 1945, the Nobel Prize in chemistry for 1944 was awarded to Otto Hahn alone-without acknowledging Lise Meitner's contribution to the discovery of nuclear fission, which historian of science Margret Rossiter called the probably "most notorious theft of Nobel credit". ${ }^{19}$ As Meitner's biographer, Ruth Lewin Sime, explained, those "who did not understand the science or the political situation concluded that the chemists had discovered fission while the physicists had merely explained it." ${ }^{20}$ And after being excluded from the Nobel Prize in 1945 Meitner largely lost her place in the history of science. ${ }^{21}$ In 1948, Meitner was offered her old position and the directorship of the Max Planck Institute for Chemistry, which had been relocated to Mainz. Yet she refused it, fearing that she "would not be able to breathe" in the post-war atmosphere. ${ }^{22}$ She became an External Scientific Member instead.

Albert Einstein had referred to Meitner as "our Madame Curie," thus recognizing Meitner's importance in the field of radioactivity and in the physics community both Einstein and Meitner inhabited in Berlin. ${ }^{23}$ It is amazing that more than a hundred years ago scientists were willing to follow Einstein's mind-blowing and ground-breaking thought experiments into the universe, but still seemed to be unable to shake off old chauvinist beliefs regarding female excellence and accomplishments in science.

19 Rossiter, 1993, p. 329.

20 Sime, 2005, p. 24.

21 For more on Meitner's scientific achievements in this context, see e.g. Sime, 2001. Crawford/Sime/Walker, 1996, 208-210. For the counter position, defending Hahn's sole accomplishment see Weizsäcker, 1997: 34.

22 "Ich glaube, ich würde in dieser Atmosphäre nicht atmen können." Meitner to Eva von Bahr-Bergius, 10 January 1948, Lise Meitner Papers, Churchill Archives Centre; quoted from Sime, 1996, pp. 353-354.

23 Frank, 2002, p. 139. 
Figure 2: The female Scientific Members of the Max Planck Society, $1948-1998^{24}$
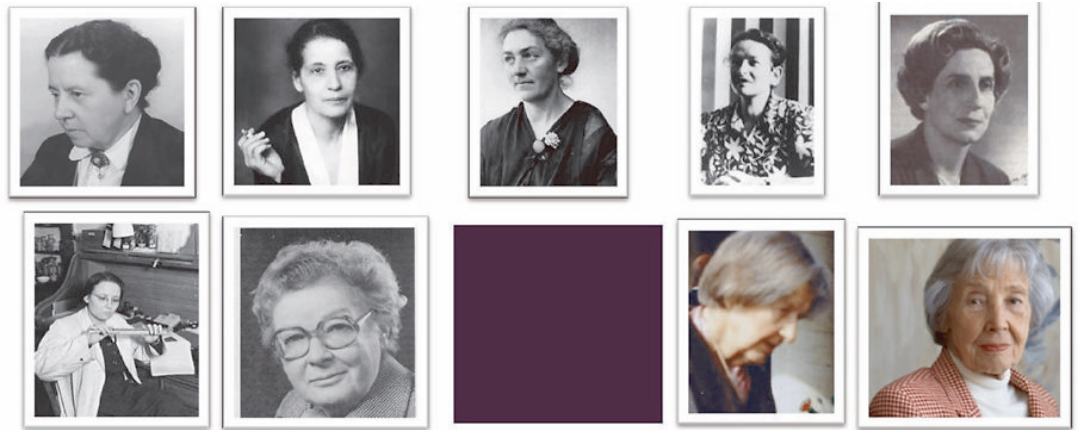

Die weiblichen Wissenschaftlichen Mitglieder, 1948-1998
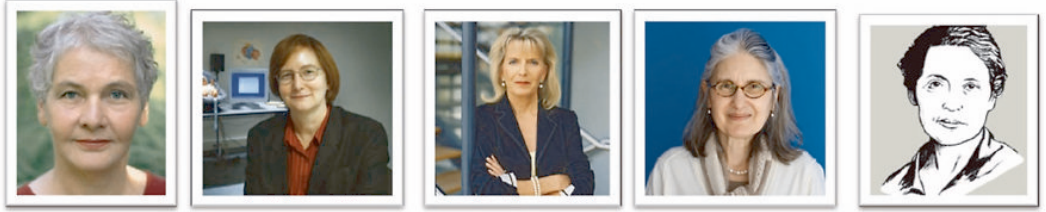

In 1998, when the Max Planck Society celebrated its fiftieth anniversary, it had all in all appointed 13 female Scientific Members (compared to 678 male Members). So how did the Max Planck Society manage to recover from these lost opportunities and eventually provide equal opportunities?

\section{EQUAL OPPORTUNITIES $S^{25}$}

Major changes in gender policy marked the decade from 1988 to 1998 at international and national level. ${ }^{26}$ However, this trend was barely reflected

24 From left to right top-down: Isolde Hausser; Lise Meitner; Elisabeth Schiemann; Anneliese Maier; Anne-Marie Staub; Birgit Vennesland; Margot Becke-Goehring; Eleonore Trefftz; Renate Mayntz; Christiane Nüsslein-Volhard; Anne Cutler; Angela D. Friederici; Lorraine Daston. Never appointed, and only member ex officio: Else Knake. (Collage made by author, copyright photos: Archive of the Max Planck Society, Berlin — henceforth: AMPG.

25 For a comprehensive study of the gender equality process and its implementation in the Max Planck Society, see Kolboske, 2018.

26 It had been preceded by the United Nations Decade for Women, 1975-1985. 
in German research institutions and universities. Despite the "best educated generation of women the Bundesrepublik ever had," 27 the insufficient participation of women at all qualification and hierarchy levels of academic life has been well documented since the mid-1990s. In 1989 the German Council of Science and Humanities had established "a pyramidal picture of women's participation at universities and colleges." ${ }^{28}$ Initiated by the German government, the Bund Länder Commission for Educational Planning and the Promotion of Research developed a report on the "Advancement of Women in the Field of Science", that was adopted in December 1989 and accompanied by a series of recommendations on how to increase the participation of women in universities and research institutions "at all levels of the qualification process in science. "29 These exogenous factors would eventually put into motion gender equality policies in the Max Planck Society, which had to address its own gender structure, if it wanted to avoid losing federal funds. In 1988, the Max Planck General Works Council published an article on the employment situation of women in the Max Planck Society stating that "merely one sixth of all the scientists working in the MPS are women". 30

Likewise, the Scientific Council of the Max Planck Society addressed the prevailing gender imbalance, and, in 1991, issued its Recommendations for the Advancement of Women in Science stating that: "The professional development of women and men that has been subjected in content, structure and socially to conditions, which have historically led to a discrimination of women in science [...] is no longer acceptable." The main message of the Recommendations was that the future tasks of science made the "timely and full development of all talents and abilities indispensable." 31 Still they focused mainly on a "better science-life-balance", whereas influencing recruitment decisions by introducing a quota system was rejected on principle. ${ }^{32}$

But not only the women on top were affected. For a comprehensive survey of the so far unchartered gender-specific employment map in Max Planck Institutes, the independent sociologist Sonja Munz was commissioned to conduct an empirical study published in 1993. Her findings included that, on average, female employees earned less than men; female

27 Munz, 1993, p. 11.

28 Wissenschaftsrat, 1988, p. 212.

29 Deutscher Bundestag: Drucksache 13/4041. 08.03.1996.

30 Ruschhaupt-Husemann/Hartung, 4/88, pp. 22-26.

31 Wissenschaftlicher Rat der Max-Planck-Gesellschaft, 2/1991, pp. 18-20.

32 Ibid.: p. 20. 
employees did more part-time work; female employees were more affected by unemployment; female employees formed a wide basis in unskilled work, whereas they were hardly represented in leading positions; and fewer women than men participated in work-related training courses. ${ }^{33}$ That is, Munz concluded, a distribution pattern could be discerned across all employment groups-granting men the well-paid, secure and influential jobs, while the representation of women diminished to the same extent in which status, gratification and stability of the positions grew.

Above all, it was the Second Federal Act on Gender Equality ${ }^{34}$ that came into effect in 1994, which finally triggered serious negotiations for equal opportunity policies in the Max Planck Society in the mid-1990s. Apart from being afraid of invoking possible sanctions in terms of losing public funds, it was the concern of losing one's traditional autonomy in recruitment and appointment processes that put the wheels into motion. An important feature of this omnibus act was the Act on the Promotion of Women. ${ }^{35}$ In its wording, it only applied to employees in the federal administration and in federal courts, and thus not immediately to the Max Planck Society. However, it set standards for future expectations on measures promoting women in institutions essentially financed by federal funds-such as the Max Planck Society. Thus it was agreed that the Act on the Promotion of Women was to serve as the base for further measures in the Max Planck Society which also took into account the "specific demands of the Max Planck Society. “36

Not surprisingly said specific demands disarmed the Act on the Promotion of Women in crucial aspects. Just some highlights to give a general idea: The obligation to increase the proportion of women did not to apply to appointments (Section 7 Article 3). Overall control for implementing the Framework for the Advancement of Women ${ }^{37}$ was not assigned to the Central Gender Equality Officer (Section 4 Article 1). ${ }^{38}$ Hence the power of the gender equality officer and the local ombudswomen was drastically

33 Munz, 1993.

34 Zweites Gleichberechtigungsgesetz (2. GleiBG).

35 Gesetz zur Förderung von Frauen und der Vereinbarkeit von Familie und Beruf in der Bundesverwaltung und den Gerichten des Bundes (Frauenfördergesetz) vom 24. Juni 1994, BGBl. I, S. 1406 ff. (=Art. 1, 2. GleiBG).

36 139. Sitzung des Senats der MPG am 24. März 1995 in Berlin, Niederschrift, TOP5 Frauenförderung in der Max-Planck-Gesellschaft, AMPG, II. Abt., Rep. 60, Nr. 139.SP, B1. 24-25.

37 The first ever Equal Opportunities Policy of the Max Planck Society.

38 No Central Gender Equality Officer existed in the Max Planck Society until October 1996, when Marlis Mirbach took up her work. She was not elected, but ap- 
limited regarding her participation in personnel matters. The hesitant, half-hearted implementation of gender equality measures resulted in a failed equal opportunities policy at this early stage. In 1998, the proportion of female scientists in senior research positions still remained dim-as illustrated by these figures: 1.8 per cent $=\mathrm{C} 4 ; 7$ per cent $=\mathrm{C} 2 / 3 ; 3.6$ per cent $=$ BAT I. ${ }^{39}$

But that was less due to the lack of appropriate measures than to the prevailing mindset. Mary Osborn (Max Planck Institute for Biophysical Chemistry) pointed out that "MPG directors are selected in a closed process by individual institutes, in a selection process in which given the current circumstances usually only men participate!" Hence she suggested female scientists (if necessary from abroad) be included on selection committees, thus drawing on appointment measures customary at Harvard since the early $1970 s .{ }^{40}$ Nancy Hopkins (MIT) was quoted in Science as saying that one has to change the institution and the minds would follow. ${ }^{41}$ That was true for the Max Planck Society; the lengthy and painstaking process of establishing gender equality also had to do with the deeply ingrained credo of scientific excellence, and the obvious difficulty in coming to terms with the fact that this was not a uniquely male quality.

Well, eventually things did change-albeit slowly. By now the gender proportion has notably changed, even if there is still a long way to parity at the top. ${ }^{42}$ But nevertheless the questions remain: Do specific rules apply for women within the Max Planck Society? Are female scientific achievements in general assessed differently? An issue, that does not appear to be trivial given that, for instance, recently only female Max Planck directors

pointed by the General Secretary: "Abweichend von $\$ 15$ FFG ist in der Max Planck Society nach vorheriger Ausschreibung durch den Generalsekretär eine zentrale Gleichstellungsbeauftragte zu bestellen. Die Bestellung erfolgt für die Dauer von drei Jahren mit der Möglichkeit der Verlängerung.” Aktenvermerk, Erster Vorentwurf einer Senatsvorlage wegen Frauenförderung FFG, 28. Oktober 1994, GVMPG, BC 207182.

$39 \mathrm{C}$ and BAT refer to the salary levels that applied according to the federal salary regulations for academic officials - professors and research scholars-in German academia between 1975 and 2002, i.e. a full university professor received C4.

40 Osborn to Hofschneider, 16 October 1991, GVMPG, BC 207181.

41 Lawler, 1999.

42 According to the official figures of the MPS: "As of December 31, 2018, the proportion of female employees was 44.4 percent. The proportion of women researchers was 15.9 per cent at W3 level, 35.1 per cent at W2 level and 32.6 per cent at the level of scientists employed under the collective agreement for the public sector; in the non-scientific areas it was 55.3 per cent." https://www.mpg.d e/facts-and-figures (14.02.2020). 
have been publicly confronted with the accusation of having bullied their employees. ${ }^{43}$

\section{SECRETARIES}

I think the word "secretary" means a girl or a woman that works for another man in the company, no matter what she does. ${ }^{44}$

\section{WHAT IS A SECRETARY?}

The noun "secretary" derives from Medieval Latin secretarius, indicating a confidential employee, that is, a prestigious job. ${ }^{45}$ Though confidentiality still remains one vital requirement of the modern secretary, much of the prestige, however, was lost with the feminization of the profession. Cambridge Dictionary provides the definition: "secretary (office worker): someone who works in an office, writing letters, making telephone calls, organizing meetings, etc. for other people" ${ }^{46}$ There are, of course, other meanings for the word; in addition to referring to a piece of furniture, it can also mean a government official: "secretary: the head of a government department: e.g. the Foreign Secretary ". ${ }^{47}$ What better example to illustrate the inherent gender gap - the first describing a traditionally female profession, the second for decades an almost exclusively male one. It seems to be the fact that office work has been viewed as women's work that makes a concise job description so difficult: "We have a problem as secretaries that nobody knows what to call us. A secretary could be a typist or it could be a full-blown personal assistant or administrative officer." 48 Over the course

43 See e.g. Rubner, 2020, p. 6.

44 Pringle, 1989, p. 1.

45 Merriam-Webster.com Dictionary, s.v. "secretary,“ accessed February 8, 2020, https:/www.merriam-webster.com/dictionary/secretary?show=0\&t=1391421751.

46 Cambridge Dictionary, https://dictionary.cambridge.org/dictionary/english/secret ary (8.2.2020). Oxford Learner's Dictionaries, however, amends: "In this meaning, secretary is starting to become old-fashioned, except in certain compounds like legal secretary and press secretary. It is now more usual to call somebody an assistant or PA. “ https://www.oxfordlearnersdictionaries.com/definition/english/secret ary (8.2.2020).

47 Cambridge Dictionary, https://dictionary.cambridge.org/dictionary/english/secret ary (8.2.2020).

48 Pringle, 1989, p. 1. 
of time it was applied to more and varied functions, describing indiscriminately both, less as well as more influential posts within the bureaucracy of institutions and businesses. Sometimes one even dispensed with the need to distinguish between humans and machines, that is, the noun "typewriter" was used for both: the machine and the person operating it. ${ }^{49}$ While there has been an impressive amount of dissertations on the topic of the typewriter (=machine) as a historiographic artefact in culture, technology and science since the 1930 ; $;{ }^{50}$ the lack of accuracy in the job description, or rather the indiscriminate use of the term "secretary" notwithstanding if referring to a personal assistant/executive assistant, administrative officer or a stenographer was for many years reflected in a lack of historiography on the person who operated that machine (not to mention: managed the office), and thus obviously the inherent lack of interest in such subordinate a position..$^{51}$ In the following: a brief historical outline of the evolution in the office-and how it became the prototype of a female profession.

49 See Saval, 2014, 75. Comprehensively and immensely entertaining: Kittler, 1986, p. 273, p. 400. Kittler was dubbed the "most distinguished intellectual enemy of the Apple universe“, Hans Gumbrecht, NZZ, 18 June 2019. In German the derogatory term "Tippse" was derived from the verb "tippen" (typing).

50 Some randomly selected titles: Hermann Popp: Kinematische und dynamische Untersuchung der Schreibmaschine, Technische Hochschule München, 1930; Hermann Reinecke: Über die handangetriebenen Anschlaggetriebe der Schreibmaschine, Technische Hochschule Braunschweig, 1953; Karlheinz Vielhauer: Die deutsche Schreibmaschinen-Industrie, Universität Frankfurt (Main), 1954; Erich Bürger: Untersuchungen an manuell angetriebenen Schreibmaschinen. Technische Hochschule Dresden, 1958; Hermann Harald Koch: Über die Kraftübertragung in einer motorisch angetriebenen Schreibmaschine, Technische Hochschule Braunschweig, 1963; Shuying Zhang: Neues Konzept einer Schreibmaschine für chinesische Schrift. Technische Universität München, 1981.

51 Among the first to distinguish between white-collar employees and secretaries were Jürgen Kocka, Gisela Brinkler-Gabler and Ursula Nienhaus, while Gabriele Rösler provided the first German thesis on the working conditions of secretaries; Kocka, 1977; Brinker-Gabler (ed.), 1979; Rösler, 1981; Nienhaus, 1982). By now the literary corpus on the subject has become quite comprehensive. 
A stenographer [...] is paid to do; a secretary is paid to think. ${ }^{52}$

Women's employment at the office is a result of the demographic shifts created by several wars. The historical development of the secretarial profession is prototypical for the feminization and subsequent (alleged) deprofessionalization described by Hicks (2017). One that, alas, proves to die hard, as for instance indicated by today's salary brackets of "secretaries/ assistants", especially in higher education. So what does a "secretary/assistant" actually do?

In a nutshell, classical paper work in the office encompassed writing and filing-evolving from copying (by hand), type-writing, taking dictation, shorthand-writing systems, multiplication with carbon copies and lithography, filing systems, cataloguing with index cards, and later via punched card systems eventually to word processing and today's "virtual" office. ${ }^{53}$ The hierarchy at the office went from typist, who typed up documents from stenographic notes or recordings or made sense out of marked-up hard copy. Next came the stenographer, who took dictation and subsequently typed up their notes or handed them to a typist. At the top of the hierarchy was the secretary, who provided support to executives (directors in the Max Planck Society) and ran the office in general. Another hierarchy existed among the secretaries themselves, depending on whether they were executive, directorial, departmental or confidential secretaries.

\section{DEXTERITY, DILLIGENCE AND PATIENCE}

It seems there are not many job titles more clearly gendered than "secretary" (well, yes: checkout girl and cleaning woman)—but until the nineteenth century, clerical office work was mainly reserved for men. The turning point for women's clerical employment came during the American Civil War (1861-1865). Male labor was scarce, so the government began hiring women for office jobs. Francis Elias Spinner (1802-1890), the former Treasurer of the United States is attributed with having initiated the

52 "Secretaries Quash Idea They Like to Romance with Their Bosses," Los Angeles Times, October 2, 1949, p. 21.

53 An excellent insight into the history and evolution of office life provides Gardey, 2019. 
employment of women in government offices. ${ }^{54} \mathrm{He}$ first contracted women to count currency bills and "later to take over various clerical duties, so that by the end of the war women had a definite status in the civil service. " 55 Not surprisingly, women did an excellent job. Thus, after the war, women continued to be employed (at least until they married) - not least due to the fact that they were paid less. "Under [US] federal law in 1866, the maximum salary for women was $\$ 900$ a year, compared with a ceiling between $\$ 1,200$ and $\$ 1,800$ for men. "56 In Germany, the paradigm of male dominated bureaucracy began to shift during the Gründerzeit following the Franco-Prussian War in 1870/71. Here too, working women were paid and respected less. In her study on the emergence of female professionals, Ursula Nienhaus estimated that a women typing approximately 37,500 characters a day on poorly engineered typewriters lifted the equivalent of 15 tons with their fingertips. ${ }^{57}$

In 1870, there were eighty thousand clerical workers in the USA; only three percent were women. Fifty years later, there were three million clerical workers, of whom women made up nearly 50 percent. ${ }^{58}$ Their dexterity, diligence and patience made women allegedly perfectly suited for the job as a secretary. In addition to being a low-income group, women became attractive employees since they were restricted to particular positions, such as stenography; that is, work that did not involve much imagination or initiative, whether it be handwritten dictation or mechanical typing. According to Nikil Saval, the reason for this was that women were considered to be better able to handle thankless work. ${ }^{59}$ The private secretary, too, gradually became identified as exclusively female. Unlike the tediousness of stenography and typing, it was the "dead-endedness" of secretarial work that supposedly made it appropriate for women, who were not expected to pursue careers. ${ }^{60}$ In 1925, efficiency disciple William Henry Leffingwell (1876-1934), famed for applying scientific management to the office, ${ }^{61}$ claimed:

54 Remarkably this high-profile position has been held exclusively by women since 1949, when then President Harry S. Truman (1884-1972) appointed actress and business woman Georgia Neese Clarke Gray (1898-1995) as the first woman to serve as Treasurer of the United States.

55 Shaw, p. 1935.

56 Cf. Strom, 1989, p. 55.

57 Nienhaus, 1982, p. 25.

58 Saval, 2014, p. 74.

59 Saval, 2014, pp. 74-75.

60 Saval, 2014, p. 76.

61 For more on industrial efficiency and F.W. Taylor in particular, see: Kanigel, 2005. 
A woman is to be preferred to the secretarial position for she is not averse to doing minor tasks, work involving the handling of petty details, which would irk and irritate ambitious young men, who usually feel that the work they are doing is of no importance if it can be performed by some person with a lower salary. ${ }^{62}$

Then, just like today (when e.g. the majority of "secretaries/assistants" in the MPS holds an academic degree) many women accepted these jobs due to a lack of alternatives and economic constraints.

But for every woman who climbed out of the steno pool and into an executive position were many others who were stymied by what came to be known in the mid-1980s as the glass ceiling: an unacknowledged but unsurpassable barrier based solely on gender. Still more were shunted into a secretarial career because there were few other choices. ${ }^{63}$

\section{TECHNOLOGICAL REVOLUTION: TYPEWRITERS AND DICTAPHONES}

Two so-called revolutions impacted the scope of secretarial activities: the technological one in the late nineteenth century, and the digital one about hundred years later. For the best part of the twentieth century, it was impossible to imagine the office without typewriters, telephones and filing cabinets. Technologies, which have been central in defining secretarial work-"and to the construction of the boss-secretary relationship." "64 The most important development was the advent of commercial (electro-)mechanical typewriter. In 1873, Remington produced the first widely used typewriter in the office. ${ }^{65}$ In 1888 , John Harrison, an expert on type-writers, deemed that the typewriter was "especially adapted to feminine fingers. They seem to be made for typewriting. The typewriting involves no hard labor and no more skill than playing the piano". ${ }^{66}$ Advertisements for typewriters were populated by "stereotypically supple-wristed female angels, their delicate, elongated piano fingers hovering expectantly over the

62 Leffingwell, 1925, p. 621.

63 Peril, 2011, p. 3.

64 Pringle, 1989, p. 175.

65 For a while in the 1940s, Remington manufactured guns as well as typewriters; it went on to produce the first UNIVAC computers in the 1950s.

66 Harrison, 1888, p. 9. For a more sophisticated assessment of women's hands on keys see Frevert, 1979, pp. 82-112. 
keys. “67 (What about brain surgery-a profession that doubtlessly demands a high level of dexterity ${ }^{68}$ ) Also around this time, the first specialized typing and shorthand schools appeared, the forerunners of the secretarial colleges, the most famous being the Katharine Gibbs College (whose graduates became known and esteemed as Gibbs' Girls ${ }^{69}$ ). Likewise crucial in changing office work were two inventions by Alexander Graham Bell: the telephone in 1870 and the Dictaphone in 1886 (using sound recording technology pioneered by Thomas Edison).

\section{DIGITAL REVOLUTION - THE VIRTUAL SECRETARY}

In 2013 British author Lucy Kellaway asked her readers "Do you remember the office before email?" And declared that by now the computer had actually become the office: it had a desktop, files, folders, documents, and a litterbin, thus combing all the "dominant metaphors" from secretarial work. ${ }^{70}$ Her colleague Emma Jacobs took things even further by pronouncing the profession of secretary dead:

In the future, personal assistants will be constructed from microprocessors and remote controlled. We are halfway there, after all. Want to dial your sales director? Ask Siri. Still determined to retain secretarial services? Then hire a virtual assistant, based in Mumbai or Brooklyn, by the hour. ${ }^{71}$

The virtual secretary in a paperless office-how did this happen? In a much-cited title story in Business Week in 1975, "The Office of The Future", George E. Pake, one of the founders of Xerox Parc predicted that the following twenty years would see a revolution in office life due to the advent of the desktop computer: "I'll be able to call up documents from my files on the screen, or by pressing a button, [...] I can get my mail or any messages. I don't know how much hard copy I'll want in this world. It will

67 Saval, 2014, p. 75.

68 Interesting enough since the early 2010s the female percentage in this profession is notably growing: in 2017, 41 out of 138 neurosurgeons were female, and among neurologists the women clearly outweighed their male colleagues: 336 out of a total of 541. https:/www.bundesaerztekammer.de/fileadmin/user_upload/do wnloads/pdf-Ordner/Statistik2017/Stat17AbbTab.pdf: (19.3.19).

69 Doherty, 2014.

70 Kellaway, 2013.

71 Jacobs, 2015. 
change our daily life, and this could be kind of scary." 72 Almost fifty years later he has been proven right. However, the 1970s idea of word processing was very different from today's:

The "buzz word" for this year's show was "word processing," or the use of electronic equipment, such as typewriters; procedures, and trained personnel to Maximize office efficiency. At the I.B.M. exhibition a girl typed on an electronic typewriter. The copy was received on a magnetic tape cassette which accepted corrections, deletions and additions and then produced a perfect letter for the boss's signature. The perfect letter could then be sent over telephone lines to other offices around the country, or the typewriter could also be used as an input device for computers. ${ }^{73}$

Figure 3: The IBM MT/ST word processor used in the mid-1960s at the Max Planck Institute for Human Development in Berlin. (C) AMPG ${ }^{74}$

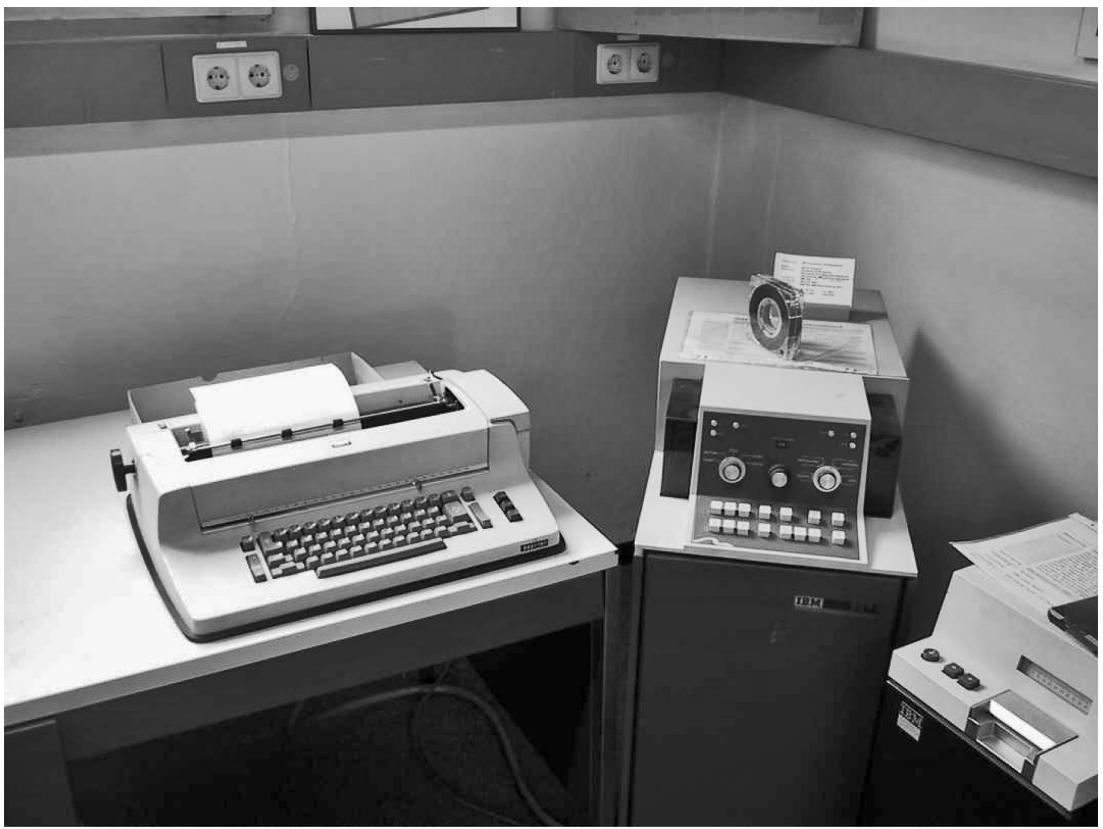

72 "The Office of the Future", 1975, p. 48.

73 Smith, 1971.

74 Betriebsrat Bildungsforschung 1967-1968, AMPG, Abt. II, Rep.43, K 29.

https://doi.org/10.5771/9783748924869-105, am 26.04.2023, 17:31:32 
Moreover one tried to sell word processing as a "feminist innovation": "According to some manufacturers, the concept of 'word processing' could be the answer to Women's Lib advocates' prayers. Word processing will replace the 'traditional secretary' and give women new administrative roles in business and industry." ${ }^{\text {" }}$ Well, it didn't quite work out like that. This had to do with the fact that word processing was to be done in pools by specialized typists working with text-editing machines. ${ }^{76}$ As Kellaway put it: "Being bumped off to the new word processing pool turned out to be only slightly more fun than punching holes in cards." 77

As computers became more sophisticated, working with them stopped being low status work and was subsequently more and more regarded as a male domain. A gendered power shift took place until eventually "computer programming aggressively altered from feminized work to a firmly masculine professional endeavour. ${ }^{\text {"78 }}$ For the majority of secretaries, word processing did not come along until the arrival of the desktop computer. ${ }^{79}$ And in the late 1980s and early 1990s, work was redistributed. According to Rosemary Pringle, office equipment and technology have been decisive for the archaic pattern that determines the power imbalance in the relationship between the secretary and her superior:

To understand why the boss-secretary relationship continues to be normatively constructed around male power and female subordination and why despite automation it may still be preserved we have to consider; the meanings attached to technology, the struggles around these meanings and the potentials attached to technology. ${ }^{80}$

This is an assessment shared by Lynn Peril, who considered that the power differential "inherent in the relationship between boss (dominant) and secretary (submissive) made it a natural for all sorts of sadomasochistic scenarios." 81

75 Smith, 1971.

76 See also, IV. IBM-Magnetband-Maschinen, Betriebsrat Bildungsforschung 19671968, AMPG, Abt. II, Rep.43, K 29, pp. 3-4.

77 Kellaway, 2013.

78 Hicks, 2017, pos. 1699.

79 On June 5, 1977 Steve Jobs and Steve Wozniak launched Apple II, the first 8-bit home computer and one of the first highly successful mass-produced microcomputer products at West Coast Computer Faire; four years later, on August 12, 1981, IBM brought out the PC.

80 Pringle, 1989 , p. 174.

81 Peril, 2011, p. 8. 
Figure 4: Job offers for different offices in the Administrative Headquarters over the course of 30 years illustrating the diversity of the field. ${ }^{82}$

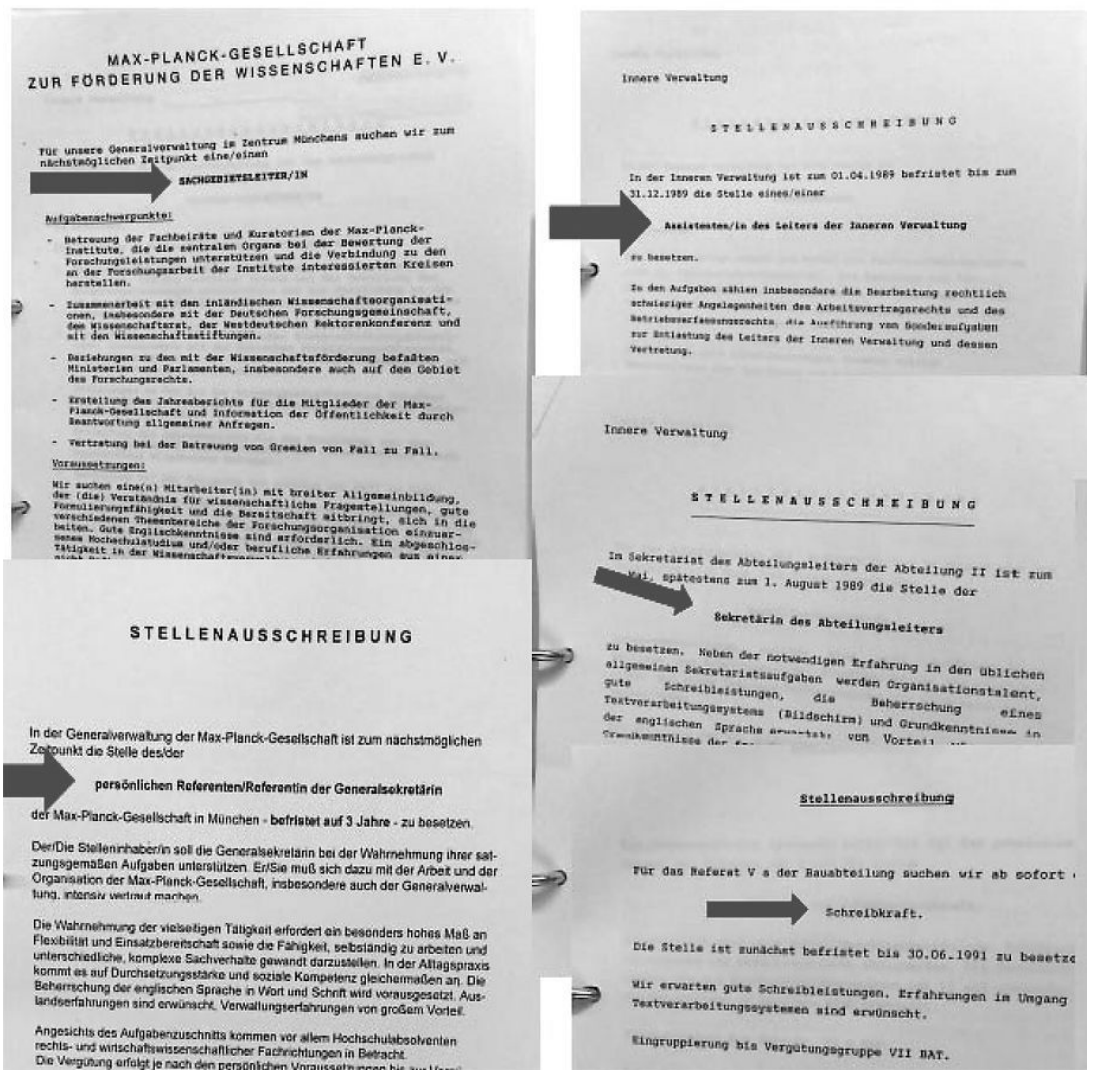

\section{JOB REQUIREMENTS IN THE MAX PLANCK SOCIETY}

It goes without saying that in the Max Planck Society classical secretarial tasks, such as correspondence, answering the phone, filing, takings notes, administrative organization and appointment coordination were and are expected from secretaries/assistants working there. Naturally, nobody needs a stenographer any more. Instead many other skills are expected,

82 Selected from job offers between 1979 and 2007 for openings in the GV; Registratur der Generalverwaltung, BC 214.993-BC 214994. 
above all excellent organizational skills as well as strong commitment, independence and a sense of responsibility. Job requirements in project/ department-related management include accounting, public relations (media and website management), business trip planning, and event management (e.g. conferences). Excellent command of English and language proficiency in at least another language is expected. Computer skills are not even mentioned any more, they are taken for granted. Specific requirements vary across the three traditional sections of the Max Planck Society: whereas in the Humanities services of editorial assistants (who are obviously no secretaries) are often required; in the Chemistry, Physics and Technology Section or in the BMS, however, where the research results may eventually lead to the filing for a patent application, assistants with an understanding of contract law are welcome. The fact that today the majority of "secretaries/assistants" in the Max Planck Society is academically trained (usually a university degree, some even $\mathrm{PhDs}$ ) comes handy in tasks requiring scientific understanding, such as drafting exposés or scientific reports (even though these tasks may not be part of the official job description).

\section{Figure 5: Otto Hahn and his secretary Marie Luise Rehder in his office in the} 1950s. (C) AMPG

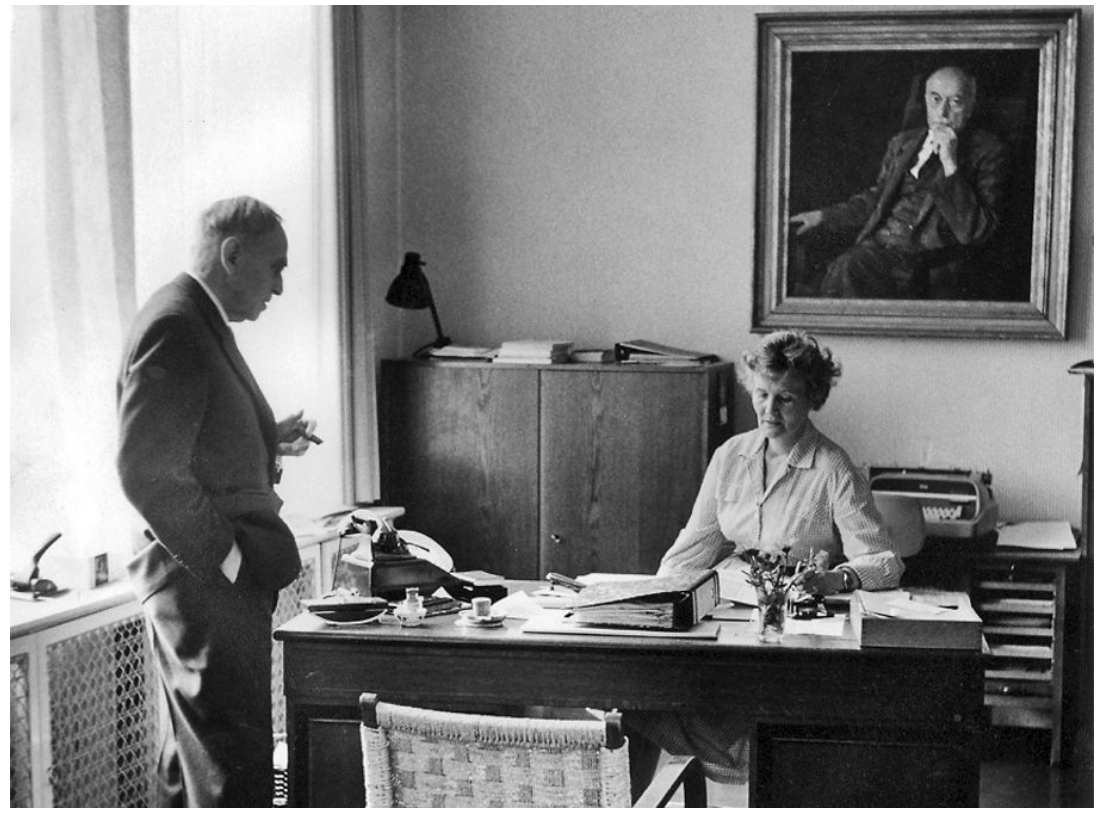


The evolution of office work within the Max Planck Society becomes clearly evident when comparing the office of the Society's first president, Otto Hahn(1948-1960), with the office of Martin Stratmann, the current president of the Max Planck Society.

Figure 6: Martin Stratmann and staff in his office, 2019. () MPG

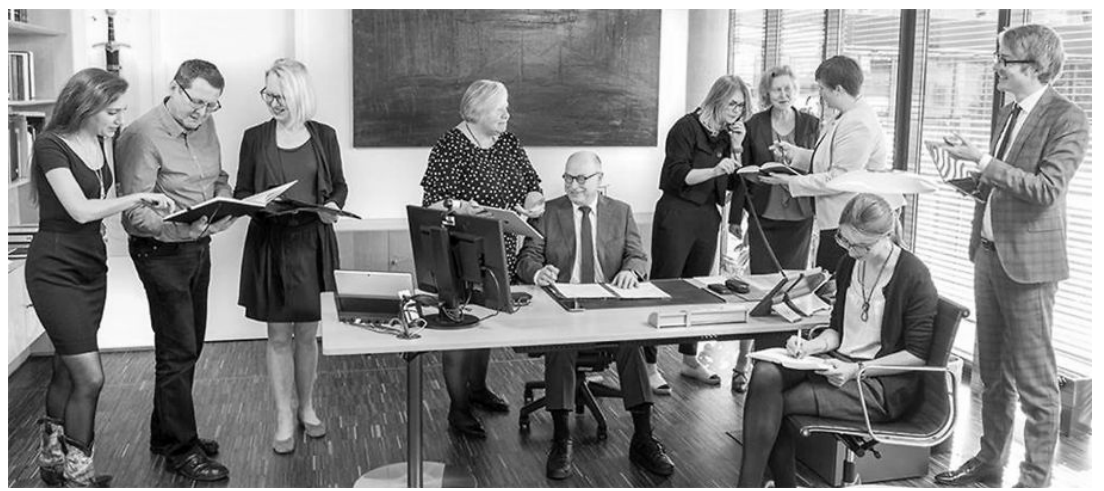

Today's scope of activities of "secretaries" (who are now called "assistants") is so comprehensive and diverse that it proved impossible for the central Personnel Department to statistically assess the number of "secretaries/ assistants" currently working at the 88 Max Planck Institutes and its Administrative Headquarters. This must mainly be attributed to the fact that the salary brackets of the office workers are so varied too. ${ }^{83}$

However, the sophistication and diversity of office work is not a recent phenomenon. The Max Planck Institute for Human Development (MPIB) addressed the challenges of office work in research culture decades ago. In the mid-1960s a multi-partied institute commission started working on an office reform, considering the creation of Central Office Centre (Zentralsekretariat). This was based on the understanding that such a specific work-sphere required to involve non-academic colleagues into the responsibility-in terms of better participation - of research projects. The idea was to create within the scope of "rationalising paper work" specific office career opportunities for the (exclusively female) employees. It was planned to provide them with incentives regarding income as well as prestige to ad-

83 Currently a guide value is being prepared with the generous help of the gender equality officers and many of the secretaries and assistants at Max Planck Institutes: Thank you so much for your support! 
vance from a typist to a Sachbearbeiterin [administrative officer] ${ }^{84}$ The scheme from 1967 traversed five levels and four subsequent promotion grades with corresponding salary brackets:

1. Secretary - VGr. VIII BAT (entry grade): employees capable of doing independently more demanding work, such as composing short pieces of writing, taking shorthand at 150 syllables per minute for at least five minutes, and subsequently typing this up into flawless German.

2. Secretary - VGr. VII BAT (first promotion grade): employees familiar with taking dictation in a foreign language or making simple translations from or into this language.

3. Administrative officer/trilingual secretary - VGr. VIb BAT (second promotion grade): employees familiar with taking dictation in two foreign languages or making simple translations from or into those languages. Employees capable of interpreting consecutively and correctly in terms of content and language between two people from German into another language and vice versa.

4. Administrative officer/multilingual secretary - VGr. Vb BAT (third promotion grade): employees, familiar with taking dictation in two foreign languages or making simple translations from or into these languages, and distinguish themselves from salary bracket VIb Fallgruppe 1 through special skills, such as even more languages. Employees involved in tasks requiring thorough and comprehensive expertise and predominantly independent achievements.

5. Technical assistant-VGr. IVb BAT (fourth promotion grade)

Employees who distinguish themselves from salary bracket $V b B A T$ by performing a particularly valuable task. ${ }^{85}$ | Scientific assistants without degrees from higher education. ${ }^{86}$

84 Betriebsrat Bildungsforschung 1967-1968, AMPG, Abt. II, Rep.43, K29. Sachbearbeiterin.

85 What would that be? Maybe operating the above-mentioned IBM MT/ST word processors that had been installed at the MPIB in 1965.

86 Based on the material from Betriebsrat Bildungsforschung 1967-1968, AMPG, Abt. II, Rep. 43, K 29 shown in fig. 7. 
Figure 7: New Organization of a Central Office Centre Pool (Zentralsekretariat) at the Max Planck Institute for Human Development in $1967^{87}$

1. Sekretärin - VGr. VIII BAT (Eingangsgruppe)

Angestellte für schwierigere Arbeiten, unter anderem: Sie müssen in der der Lage sein, einen Teil ihrer Arbeiten selbständig zu erledigen , z. B. kurze Schriftstïcke nach Ansage selbständig abzufassen, 150 Silben Stenogramm in der Minute mindestens fünf Minuten lang aufzunehmen und schnell in fehlerfreier deutsche Sprache in Maschinenschrift zu übertragen.

2. Sekretärin - VGr. VII BAT (erste Beförderungsstufe) Angestellte, die in einer fremden Sprache geläufig nach Diktat schreiben oder einfache Übersetzungen aus dieser oder in diese Sprache anfertigen.

3. Sachbearbeiterin/Fremdsprachliche Sekretärin - VGr. VIb BAT (zweite Beförderungsstufe)

Angestellte, die in zwei fremden Sprachen geläufig nach Diktat schreiben oder einfache Übersetzungen aus diesen oder in diese Sprachen anfertigen

Angestellte, die Gespräche zwischen zwei Personen satzweise inhaltlich und sprachlich richtig Sprachen aus dem Deutschen in eine fremde Sprache und umgekehrt mündlich übertragen.

4. Sachbearbeiterin/Fremdsprachliche Sekretärin - VGr. Vb BAT (dritte

Beförderungsstufe)

Angestellte, die in zwei fremden Sprachen geläufig nach Diktat schreiben oder einfache Übersetzungen aus diesen oder in diese Sprachen anfertigen und sich durch besondere Leistungen aus der Vergïtungsgruppe VIb Fallgruppe 1 herausheben (z.B. noch mehr Sprachen)

Angestellte, in Tätigkeiten, die gründliche, umfassende Fachkenntnisse und überwiegend selbständige Leistungen erfordern.

5. Technische Assistentin - VGr. IVb BAT (vierte Beförderungsstufe) Angestellte, die sich aus der Vergütungsgruppe V B BAT dadurch herausheben, dass sie eine besonders wertvolle Tätigkeit ausïben.

Wissenschaftliche Assistenten ohne abgeschlossene Hochschulbildung an Hochschulinstituten.

The issue of secretaries remained a matter of interest at the MPIB, when in 1975 a "Secretaries' Commission" (Sekretärinnen-Kommission) ${ }^{88}$ was established, led by the then head of administration Horstmar Hale that focused on optimizing the organization of office work. In their report in January 1976, they compared and considered the disadvantages and benefits of assigning one secretary to (a) each scientist, or (b) to workings groups, or (c) to work with one secretary pool (elegantly called "Kanzlei") in charge of all paperwork, which was to be managed by administration and not by the directors (spoiler alert: did not work out).

Notwithstanding the many new technological skills in the profession that replaced others no longer needed, such as shorthand or mixing Martinis, there are other, rather soft skills that distinguished secretaries then and

87 Betriebsrat Bildungsforschung 1967-1968, AMPG, Abt. II, Rep. 43, K29.

88 Sekretärinnenkommission Bildungsforschung 1975-1976, AMPG, Abt. II, Rep. 43, K 34, Bd. 6. 
remain crucial to this day. ${ }^{89}$ Apart from excellent organizational skills, strong commitment, and a sense of responsibility, these include skills determining the relationship between assistant and superior. The days of ante-chambers may be over, ${ }^{90}$ where each director had "an official 'gatekeeper', a female secretary whose position as intermediary is structured architecturally, by being situated in a room one must pass through to access the office of the director; "911 however, the secretary/assistant is still expected to remain her superior's keeper in terms of confidentiality and trust. A working relationship is founded on mutual trust. Once this trust is shaken, or even breached, the power-makeup in this intrinsic hierarchical (and for the longest of times, patriarchal) relationship may flip-and not in a good way.

\section{FROM SCIENCE SUPPORTERS TO SCIENCE MANAGERS}

Recent studies have increasingly recognized that contemporary office work at the top echelon of higher education can no longer be regarded as merely "supporting"-the science supporters have become science managers in their own right. ${ }^{92}$

At the Humboldt University in Berlin, a research project run over three years (2013-2016) investigated over three years (2013-2016) the "Transformation of Work in Science-Supporting Areas at Universities“, and provided an empirical study analyzing the changing work requirements and occupational conditions of the science supporting staff in offices, libraries, laboratories, data centers and administrative bodies at universities and the forces driving that change. ${ }^{93}$

89 As confirmed by the testaments of such extraordinary presidential secretaries as Herta Fricke and Martina Walcher, or Brigitte Weber-Bosse, the first secretary of the CPTS.

90 Referring to the common architectural structure described by Vita Peacock: "The directors, meanwhile will often be situated on the top floors of the building, with large comfortable offices accessible through the ante-chambers of their secretaries'. Peacock, 2014, p. 59.

91 Peacock, 2014, p. 140.

92 Banscherus/Friedrich-Ebert-Stiftung (eds.), 2009; Ulf Banscherus et al., 2017; Whitchurch, 2015, pp. 79-99; Frei/Mangold (eds.), 2015).

93 "Wandel der Arbeit in wissenschaftsunterstützenden Bereichen an Hochschulen" https://www.zewk.tu-berlin.de/fileadmin/f12/Downloads/koop/publikationen/Bi wuB-Doku.pdf. 
An increasing number of staff in research institutions with both academic and professional credentials find themselves working in a multi-disciplinary environment, which requires a blend of academic and professional input and interaction. With the "Third Space" environment, Celia Whitchurch provided a concept to approach the conflicts stemming from the institutional interface between academic and non-academic professionals. ${ }^{94}$ "The concept is used as a way of exploring groups of staff in higher education who do not fit conventional binary descriptors such as those enshrined in 'academic' or 'non-academic' employment categories. "95 Such hybrid work environments are commonplace in today's diverse research culture in the Max Planck Society. Former binary approaches to scientific communities seem outdated and problematic in viewing the roles, identities and working practices of staff. A hybrid approach seems even more fitting in such a hierarchical work environment, where many of the women working in subordinated positions are academics themselves.

Alban Frei portrayed "The Science Manageress": 96 his postmodern science manageress is located at the interface between science and business, Frei calls her a "border crosser between academic science and economic business culture" ${ }^{97}$ In a job description, her tasks would include assisting the executive director in any aspect of science management with a focus on commercial and personnel law administration for federal and third party funds. Further responsibilities may involve public relations, advancement of junior research groups, quality management and possibly becoming the institute's gender equality officer. Her CV would have to feature a $\mathrm{PhD}$, relevant management experience, expertise in personnel management, communication skills and team spirit. ${ }^{98}$ Admittedly, Frei's job description sounds rather like an ad for a research coordinator (a position still predominantly, though not exclusively held by men in the Max Planck Society) than for an executive secretary/assistant, but it is by no means far-fetched, as proven by current job advertisements. ${ }^{99}$ Furthermore, looking at the assignments and achievements of legendary secretary Erika Bollmann (19011997), who served in both, the Kaiser Wilhelm Society and the Max Planck

94 Whitchurch, 2013.

95 Whitchurch, 2013, p. 80.

96 Frei, 2015, pp. 243-256.

97 "[S]ie ist eine Grenzgängerin zwischen akademischer Wissenschafts- und betriebswirtschaftlicher Unternehmenskultur." Frei, 2015, p. 244.

98 Frei, 2015, p. 244.

99 https://jobs.zeit.de/jobs/projekt-und-arbeitsgruppenmanager-m-w-max-planck-gese llschaft-zur-foerderung-der-wissenschaften-e-v-berlin-1001818. 
Society under "eleven presidents" starting in 1936, it seems as if this is not only a postmodern job profile. ${ }^{100}$ But at long last the title is changing.

\section{REFERENCES}

Abbate, Janet. (2017). Recoding Gender. Womens Changing Participation in Computing. MIT Press. https://mitpress.mit.edu/books/recoding-gender

Acker, Joan. (1990). Hierarchies, Jobs, Bodies. A Theory of Gendered Organizations. Gender \& Society, 4(2), 139-158. https://doi.org/10.1177/08912439000400 2002

Banscherus, Ulf, Alena Baumgärtner, Uta Böhm, Olga Golubchykova, Susanne Schmitt and Andrä Wolter. (2017). Wandel der Arbeit in wissenschaftsunterstützenden Bereichen an Hochschulen: Hochschulreformen und Verwaltungsmodernisierung aus Sicht der Beschäftigten. Hans-Böckler-Stiftung.

Banscherus, Ulf and Friedrich-Ebert-Stiftung (Eds.). (2009). Arbeitsplatz Hochschule. Zum Wandel von Arbeit und Beschäftigung in der»unternehmerischen Universität«. Memorandum des Arbeitskreises Dienstleistungen. Friedrich-Ebert-Stiftung, Abt. Wirtschafts- und Sozialpolitik. http://library.f es.de/pdf-files/wiso/06669.pdf

Bollmann, Erika. (1956). Erinnerungen und Tatsachen. Die Kaiser-WilhelmGesellschaft zur Förderung der Wissenschaften. Göttingen—Berlin 1945/1946. Thieme.

Brinker-Gabler, Gisela (Ed.). (1979). Frauenarbeit und Beruf. Fischer Taschenbuch Verlag.

Crawford, Elisabeth, Ruth Lewin Sime and Mark Walker. (1997). Die Kernspaltung und ihr Preis. Warum nur Otto Hahn den Nobelpreis erhielt, Otto Frisch, Lise Meitner und Fritz Straßmann dagegen nicht berücksichtigt wurden. Kultur und Technik, 2, 30-35.

Doherty, Rose A. (2014). Katharine Gibbs. Beyond White Gloves. Createspace.

Frank, Philipp. (2002). Einstein. His Life and Times.

Frei, Alban. (2015). Die Wissenschaftsmanagerin. In Alban Frei and Hannes Mangold (Eds.), Das Personal der Postmoderne (243-256). Transcript.

Frei, Alban and Hannes Mangold (Eds.). (2015). Das Personal der Postmoderne. Inventur einer Epoche. Transcript.

Frevert, Ute. (1979). Vom Klavier zur Schreibmaschine - Weiblicher Arbeitsmarkt und Rollenzuweisungen am Beispiel der weiblichen Angestellten in der Weimarer Republik. In Anette Kuhn and Gerhard Schneider (Eds.), Frauen in der Geschichte: Frauenrechte und die gesellschaftliche Arbeit der Frauen im Wandel. Fachwissenschaftliche und fachdidaktische Studien zur Geschichte der Frauen (volume 1, 82-112). Pädagogischer Verlag Schwann.

100 For more background on Bollmann, see Globig, 1997, 47-53; Bollmann, 1956. 
Friederici, Angela. (2019). Institutioneller Wandel allein reicht nicht. In Ute Weber and Birgit Kolboske (Eds.), 50 Jahre später - 50 Jahre weiter? Kämpfe und Errungenschaften der Frauenbewegung nach 1968. Eine Bilanz. Max-PlanckGesellschaft.

Gardey, Delphine. (2019). Schreiben, Rechnen, Ablegen. Wie eine Revolution des Bürolebens unsere Gesellschaft verändert hat. Konstanz University Press.

Globig, Michael. (1997). Sechs Jahrzehnte der Wissenschaft verbunden. Erika Bollmann im Gespräch mit dem MPG-Spiegel über ihre Zeit als Mitarbeiterin und Förderin bei der Kaiser-Wilhelm-/Max-Planck-Gesellschaft. MPG-Spiegel, 5/6, 47-53.

Hachtmann, Rüdiger. (2007). Wissenschaftsmanagement im»Dritten Reich«: Geschichte der Generalverwaltung der Kaiser-Wilhelm-Gesellschaft. Wallstein.

Harrison, John. (1888). A Manual of the Type-Writer. I. Pitman \& Sons.

Heim, Susanne. (2002). „Die reine Luft der wissenschaftlichen Forschung.«Zum Selbstverständnis der Wissenschaftler der Kaiser-Wilhelm-Gesellschaft (Bd. 7). Forschungsprogramm »Geschichte der Kaiser-Wilhelm-Gesellschaft im Nationalsozialismus«.

Hicks, Marie. (2017). Programmed Inequality. How Britain Discarded Women Technologists and Lost Its Edge in Computing (eBook). The MIT Press. https://i eeexplore.ieee.org/book/7904022?bknumber=7904022

Jacobs, Emma. (2015, March 26). The Case of the Vanishing Secretary. Financial Times. Retrieved February 17, 2020, from https:/www.ft.com/content/9420a7b0 -d159-11e4-98a4-00144feab7de.

Kanigel, Robert. (2005). The One Best Way. Frederick Winslow Taylor and the Enigma of Efficiency. MIT Press.

Kellaway, Lucy. (2013, August 1). How the Computer Changed the Office Forever. BBC News Magazine. Retrieved February 17, 2020, https:/www.bbc.com/news/ magazine-23509153.

Kittler, Friedrich A. (1986). Grammophon, Film, Typewriter. Brinkmann \& Bose.

Kocka, Jürgen. (1977). Angestellte zwischen Faschismus und Demokratie: Zur politischen Sozialgeschichte der Angestellten, USA 1890-1940 im internationalen Vergleich (1. Aufl). Vandenhoeck \& Ruprecht.

Kolboske, Birgit. (2018). Die Anfänge. Chancengleichheit in der Max-PlanckGesellschaft, 1988-1998. Ein Aufbruch mit Hindernissen. GMPG

Kubicki, Karol and Siegward Lönnendonker (Eds.). (2002). 50 Jahre Freie Universität Berlin (1948-1998) aus der Sicht von Zeitzeugen. Zentrale Universitätsdruckerei.

Lawler, Andrew. (1999). From MIT, a Primer on Boosting Women's Status. Science, 286(5443), 1278-1278. https://doi.org/10.1126/science.286.5443.1278

Leffingwell, William Henry. (1925). Office Management - Principles and Practice. A.W. Shaw Company.

Max-Planck-Gesellschaft. (1974). Zahlenspiegel der Max-Planck-Gesellschaft 1974. 
Munz, Sonja. (1993). Eine empirische Untersuchung zur Beschäftigungssituation von Männern und Frauen in der Max-Planck-Gesellschaft. MPG.

N. N. (1996). Klaglos im Keller. Der Spiegel, 21, 208-210.

Nienhaus, Ursula. (1982). Berufsstand weiblich. Transit.

Nürnberg, Reiner, Ekkehard Höxtermann und Martina Voigt (Eds.). (2014). Elisabeth Schiemann 1881-1972: Vom AufBruch der Genetik und der Frauen in den UmBrüchen des 20. Jahrhunderts. Basilisken-Presse.

Peacock, Vita S. (2014). We, the Max Planck Society. A Study of Hierarchy in Germany. Doctoral thesis, University College London.

Peril, Lynn. (2011). Swimming in the Steno Pool. A Retro Guide to Making it in the Office. W.W. Norton \& Co.

Pringle, Rosemary. (1989). Secretaries Talk. Sexuality, Power, and Work. Verso.

Rösler, Gabriele. (1981). Entwicklung der Arbeitsbedingungen von Sekretärinnen [Diplomarbeit in Soziologie]. FU Berlin.

Rossiter, Margaret. (1993). The Matthew Matilda Effect in Science. Social Studies of Science, 23(2), 325-341.

Rubner, Jeanne (2020). Die Angeklagten. Die ZEIT, 39.

Saval, Nikil (2014). Cubed-A Secret History of the Workplace. Doubleday.

Scheich, Elvira. (1997). Science, Politics, and Morality. The Relationship of Lise Meitner and Elisabeth Schiemann. Osiris, 12, 143-168.

Scheich, Elvira. (2002). Elisabeth Schiemann (1881-1972). Patriotin im Zwiespalt. In Susanne Heim (Ed.), Autarkie und Ostexpansion. Pflanzenzucht und Agrarforschung im Nationalsozialismus (S. 250-279). Wallstein.

Shaw, William Bristol. (1935). Spinner, Francis Elias. In Dictionary of American Biography (volume 17, 460). Charles Scribner's Sons. https://archive.org/details/i n.ernet.dli.2015.425644/page/n471

Sime, Ruth Lewin. (1996). Lise Meitner. A Life in Physics. University of California Press. http://www.ucpress.edu/book.php?isbn=9780520208605

Sime, Ruth Lewin. (2001). Lise Meitner. Ein Leben für die Physik. Insel Verlag.

Sime, Ruth Lewin. (2005). From Exceptional Prominence to Prominent Exception. Lise Meitner at the Kaiser Wilhelm Institute for Chemistry (24). Forschungsprogramm »Geschichte der Kaiser-Wilhelm-Gesellschaft im Nationalsozialismus«.

Smith, William D. (1971, Oktober 26). Lag Persists for Business Equipment. New York Times, 59.

Strom, Sharon Hartmann (1989). »Light Manufacturing«. The Feminization of American Office Work, 1900-1930. Industrial and Labor Relations Review, 43(1), 53. https://doi.org/10.2307/2523208

Strom, Sharon Hartmann. (1992). Beyond the Typewriter. Gender, Class, and the Origins of Modern American Office Work, 1900-1930. University of Illinois Press. https://www.press.uillinois.edu/books/catalog/69dtt4cn9780252064258.ht $\mathrm{ml}$ 
Vogt, Annette. (2007). Vom Hintereingang zum Hauptportal?: Lise Meitner und ihre Kolleginnen an der Berliner Universität und in der Kaiser-WilhelmGesellschaft. Steiner.

Weizsäcker, Carl Friedrich von. (1997). Keine Geschichtsklitterei. Stellungnahme (1996). Kultur und Technik, 2, 34.

Whitchurch, Celia. (2013). Reconstructing identities in higher education: The rise of »third space « professionals. Routledge.

Whitchurch, Celia. (2015). The Rise of Third Space Professionals: Paradoxes and Dilemmas. In Ulrich Teichler and William K. Cummings (Eds.), Forming, Recruiting and Managing the Academic Profession (S. 79-99). Springer International Publishing. https://doi.org/10.1007/978-3-319-16080-1_5

\section{ABOUT THE AUTHOR}

\section{Birgit Kolboske}

Birgit Kolboske is a research scholar in the research program "History of the Max Planck Society" (GMPG) at Max-Planck-Institute for the History of Science in Berlin. Her research focus is the history of women and gender in the Max Planck Society from 1948 to 2002, with a focus on the changes in women's career paths in the context of the development of the Max Planck Society into a modern research institution oriented towards gender equality policy. Birgit Kolboske studied political science, Latin American studies and linguistics at the Free University of Berlin and semiotics at the Technical University of Berlin.

\section{Selected Publications:}

2019 (edited with Ulla Weber): 50 Jahre später - 50 Jahre weiter? Kämpfe und Errungenschaften der Frauenbewegung nach 1968. Eine Bilanz. Berlin, München.

2018. Die Anfänge. Chancengleichheit in der Max-Planck-Gesellschaft, 1988-1998. Ein Aufbruch mit Hindernissen. Ergebnisse des GMPG-Forschungsprogramms. Berlin.

2016 (edited with Axel C. Hüntelmann, Ina Heumann, Susanne Heim, Regina Fritz and Roman Birke). Wissen, Macht, Geschlecht. Ein ABC der transnationalen Zeitgeschichte. Berlin.

2015 [1995]. Guerillaliteratur - Genre und Gender. Über Gattung und Geschlechterverhältnis in der Literatur des lateinamerikanischen Widerstandes. Berlin. 


\section{ABOUT THE INSTITUTE}

Max Planck Institute for the History of Science

The Research Program "History of the Max Planck Society" (Geschichte der Max-Planck-Gesellschaft, GMPG) emerged from Department I of the Institute and its work on the historical epistemology of scientific institutions. Its aim is a comprehensive analysis of the Max Planck Society's history embedded in the contexts of contemporary history and history of science. The research period under investigation starts with the Society's foundation in 1948 and ends with the presidency of Hubert Markl in 2002. As a result of the former presidential commission on the history of the Kaiser Wilhelm Society during National Socialism as well as the completion of the Aufbau Ost program, the investigation will be extended until 2005. The research program has a focus on the dynamic interactions between research practice and institutional history; on changes in the working methods and research objectives of the Max Planck Society; and on the Society's local and global networks, and how these are embedded in science, society, and politics. Given that more than 80 institutes existed in

2002, plus 20 more that have been closed since 1948, the objective is not so much to investigate the history of individual institutes but rather to take a comprehensive approach allowing us to study clusters of institutes active in the same scientific field. 